$\begin{array}{ll}\text { Research Square } & \begin{array}{l}\text { Preprints are preliminary reports that have not undergone peer review. } \\ \text { They should not be considered conclusive, used to inform clinical practice, } \\ \text { or referenced by the media as validated information. }\end{array}\end{array}$

\title{
Cyphellostereum Ushima Sp. Nov. (Hygrophoraceae, Agaricales) Described from Amami-Oshima Island (Kagoshima Prefecture, Ryukyu Islands), Japan, with Ultrastructural Observations of its Rhizonema Photobiont Filaments Penetrated Longitudinally by a Central Haustorium
}

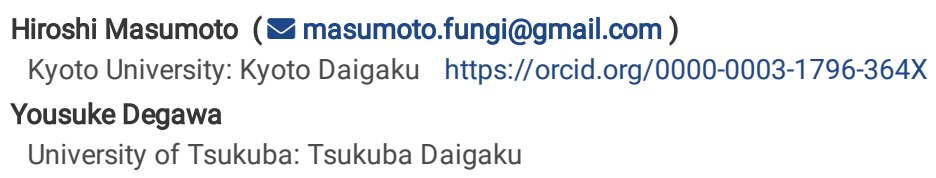




\section{Abstract}

We collected a resupinate fungus lichenized with filamentous Rhizonema cyanobacteria in Amami-Oshima Island, Japan. Microscopic observations and molecular phylogenetic analyses of both the basidioma and the lichenized thallus indicated affinities within Cyphellostereum, the first record of this basidiomycete genus from Japan. Its unique combination of structural characters and ITS rDNA sequences suggest a new species, described here as $C$. ushima. Light and transmission electron microscopic observations revealed tubular intracellular haustoria penetrating longitudinally within the cyanobacterial cells, a feature typically seen in the related genus Dictyonema, but unusual in Cyphellostereum. The generic circumscription of Cyphellostereum was therefore emended to include features of $C$. ushima and other recently described species that deviate from the conventional definition of the genus. Ultrastructural details of symbiont interactions are provided for the first time in this genus. We also succeeded in cultivating the fungus from hyphae regenerated from thallus fragments, and include a brief description of those results.

TreeBASE reviewer access URL:

http://purl.org/phylo/treebase/phylows/study/TB2:S28437?x-access-code=84d2007afb05bd743f34101ac2d97dac\&format=html

\section{Introduction}

The genus Cyphellostereum D.A. Reid was established in 1965 to include four species, based only on structures of the stipitate and cyphelloid (fan-shaped) fruiting body (Reid 1965); the relationship with algae was not noticed at that time. It was Oberwinkler (1970) who first recognized that Cyphellosteum is lichenized. He observed the mycelium of $C$. pusiolum (as Clavaria sp.) surrounding a cluster of green algae and trichomes of filamentous cyanobacteria in a Venezuelan collection. Since Cyphellostereum was rarely collected, it remained a poorly understood group. More recently, investigators have focused attention upon lichenized basidiomycetes, especially in tropical and subtropical regions (e.g., Yánez et al. 2012; Lücking and Timdal 2016; Dal Forno et al. 2017; Dal Forno et al. 2019). This has led to the description of some additional species, and the surprising placement of the genus in Hygrophoraceae (Lawrey et al. 2009; Lodge et al. 2014). Eleven species of Cyphellostereum are recognized at present (Table 1). Descriptions of each taxon in Cyphellostereum differ greatly depending on whether the species in question was regarded as a mushroom or a lichen; the former lack data on the lichenized thallus, the latter on basidia and basidiospores. Thus, the species of Cyphellostereum have never been described with the morphology of both the matured basidioma and the lichenized thallus taken into account for the same taxa, thereby hindering a holistic understanding of the genus Cyphellostereum and its species. 
Table 1

Morphological comparison of Cyphellostereum ushima with currently recognized 11 Cyphellostereum and 3 Athelia species associated with filamentous

\begin{tabular}{|c|c|c|c|c|c|c|c|c|c|}
\hline Taxon & $\begin{array}{l}\text { Hymenophore } \\
\text { type }\end{array}$ & Basidia & Basidiospores & $\begin{array}{l}\text { Cyanobacterial } \\
\text { filaments }\end{array}$ & $\begin{array}{l}\text { Hyphal } \\
\text { sheath }\end{array}$ & $\begin{array}{l}\text { Intracellular } \\
\text { haustoria }\end{array}$ & $\begin{array}{l}\text { Clamp } \\
\text { connections }\end{array}$ & $\begin{array}{l}\text { Type } \\
\text { locality }\end{array}$ & $\begin{array}{l}\text { Sequer } \\
\text { data }\end{array}$ \\
\hline \multirow[t]{2}{*}{ C. ushima } & \multirow[t]{2}{*}{ resupinate } & $\begin{array}{l}\text { clavate to } \\
\text { short- } \\
\text { cylindrical; }\end{array}$ & $\begin{array}{l}\text { ellipsoid to } \\
\text { slightly } \\
\text { elongate; }\end{array}$ & \multirow[t]{2}{*}{$\begin{array}{l}5.5-8.6 \times 3.3- \\
7.3 \mu \mathrm{m}\end{array}$} & \multirow[t]{2}{*}{$\begin{array}{l}\text { irregular } \\
\text { and } \\
\text { leaving } \\
\text { interspaces }\end{array}$} & \multirow[t]{2}{*}{ Present } & \multirow[t]{2}{*}{ Absent } & \multirow[t]{2}{*}{ Japan } & \multirow[t]{2}{*}{$\begin{array}{l}\text { ITS, } \\
\text { nuLSU }\end{array}$} \\
\hline & & $\begin{array}{l}9.4-13.0 \times \\
5.4-6.5 \mu \mathrm{m}\end{array}$ & $\begin{array}{l}5.3-6.3 \times \\
3.4-4.0 \mu \mathrm{m}\end{array}$ & & & & & & \\
\hline C. bicolor & $\begin{array}{l}\text { irregular, } \\
\text { resupinate }\end{array}$ & not observed & not observed & $7-9 \times 5-6 \mu \mathrm{m}$ & $\begin{array}{l}\text { irregular } \\
\text { and } \\
\text { leaving } \\
\text { interspaces }\end{array}$ & Absent & Absent & Mauritius & Absent \\
\hline \multirow[t]{2}{*}{ C. brasiliense } & \multirow{2}{*}{$\begin{array}{l}\text { pileate, } \\
\text { roundly to } \\
\text { slightly } \\
\text { spatulate }\end{array}$} & & \multirow{2}{*}{$\begin{array}{l}\text { oblong } \\
\text { ellipsoid; } \\
7-8 \times 3.5- \\
4.5 \mu \mathrm{m}\end{array}$} & \multirow[t]{2}{*}{ no data } & \multirow[t]{2}{*}{ no data } & \multirow[t]{2}{*}{ no data } & \multirow[t]{2}{*}{ Absent } & \multirow[t]{2}{*}{ Brazil } & \multirow[t]{2}{*}{ Absent } \\
\hline & & $\begin{array}{l}18-25 \times 5-6 \\
\mu \mathrm{m}\end{array}$ & & & & & & & \\
\hline $\begin{array}{l}\text { C. } \\
\text { galapagoense }\end{array}$ & not observed & not observed & not observed & $\begin{array}{l}7-10 \times 5-10 \\
\mu \mathrm{m}\end{array}$ & $\begin{array}{l}\text { jigsaw- } \\
\text { puzzle- } \\
\text { shaped, } \\
\text { completely } \\
\text { closed }\end{array}$ & Present & Absent & Ecuador & ITS \\
\hline $\begin{array}{l}\text { C. } \\
\text { georgianum }\end{array}$ & $\begin{array}{l}\text { resupinate to } \\
\text { corticioid }\end{array}$ & not observed & not observed & $\begin{array}{l}7-12.5 \times 5-10 \\
\mu \mathrm{m}\end{array}$ & $\begin{array}{l}\text { irregular } \\
\text { and } \\
\text { leaving } \\
\text { interspaces }\end{array}$ & Absent & Present & USA & ITS \\
\hline $\begin{array}{l}\text { C. } \\
\text { imperfectum }\end{array}$ & not observed & not observed & not observed & $\begin{array}{l}7-10 \times 3-6 \\
\mu \mathrm{m}\end{array}$ & $\begin{array}{l}\text { irregular } \\
\text { and } \\
\text { leaving } \\
\text { interspaces }\end{array}$ & no data & Absent & Guatemala & $\begin{array}{l}\text { ITS, } \\
\text { nuLSU, } \\
\text { rpb2 }\end{array}$ \\
\hline $\begin{array}{l}\text { C. } \\
\text { jamesianum }\end{array}$ & resupinate & not observed & not observed & $\begin{array}{l}11-13 \times 4-6 \\
\mu \mathrm{m}\end{array}$ & $\begin{array}{l}\text { irregular } \\
\text { and } \\
\text { leaving } \\
\text { interspaces }\end{array}$ & Absent & Present & USA & ITS \\
\hline C. muscicola & spathulate & $20 \times 4 \mu \mathrm{m}$ & not observed & no data & no data & no data & Absent & Java & Absent \\
\hline $\begin{array}{l}\text { C. } \\
\text { phyllogenum }\end{array}$ & not observed & not observed & not observed & $\begin{array}{l}6-12 \times \text { up to } 7 \\
\mu \mathrm{m}\end{array}$ & $\begin{array}{l}\text { ? ("with a } \\
\text { regular } \\
\text { hyphal } \\
\text { shell") }\end{array}$ & no data & Absent & $\begin{array}{l}\text { Borneo } \\
\text { (lectotype) }\end{array}$ & $\begin{array}{l}\text { ITS, } \\
\text { nuLSU }\end{array}$ \\
\hline \multirow[t]{2}{*}{ C. pusiolum } & \multirow[t]{2}{*}{$\begin{array}{l}\text { dimidiate } \\
\text { flabelliform or } \\
\text { spathulate }\end{array}$} & \multirow{2}{*}{$\begin{array}{l}\text { cylindrical to } \\
\text { subcylindrical; } \\
10-26 \times 3.5- \\
5 \mu \mathrm{m}\end{array}$} & $\begin{array}{l}\text { ellipsoid to } \\
\text { pip-shaped; }\end{array}$ & \multirow[t]{2}{*}{ no data } & \multirow[t]{2}{*}{ no data } & \multirow[t]{2}{*}{ no data } & \multirow[t]{2}{*}{ Absent } & \multirow[t]{2}{*}{ Cuba } & \multirow[t]{2}{*}{$\begin{array}{l}\text { ITS, } \\
\text { nuLSU, } \\
\text { rpb2 }\end{array}$} \\
\hline & & & $\begin{array}{l}5-8 \times 3-4 \\
\mu \mathrm{m}\end{array}$ & & & & & & \\
\hline C. rivulorum & $\begin{array}{l}\text { shortly } \\
\text { stipitate }\end{array}$ & $\begin{array}{l}\text { clavate; } 30 \times \\
5 \mu \mathrm{m}\end{array}$ & $\begin{array}{l}2.5-3.5 \times 2- \\
2.5 \mu \mathrm{m}\end{array}$ & no data & no data & no data & Absent & Cuba & Absent \\
\hline $\begin{array}{l}\text { C. } \\
\text { unoquinoum }\end{array}$ & not observed & not observed & not observed & $\begin{array}{l}7.5-11 \times 5-7 \\
\mu \mathrm{m}\end{array}$ & $\begin{array}{l}\text { irregular } \\
\text { and } \\
\text { leaving } \\
\text { interspaces }\end{array}$ & Absent & Absent & Ecuador & ITS \\
\hline \multirow[t]{3}{*}{ A. andina } & \multirow[t]{3}{*}{ resupinate } & $\begin{array}{l}\text { broadly } \\
\text { cylindrical to } \\
\text { clavate; }\end{array}$ & $\begin{array}{l}\text { broadly } \\
\text { ellipsoidal; }\end{array}$ & \multirow[t]{3}{*}{$\begin{array}{l}(9-10 \times 3-6 \\
\mu \mathrm{m})^{b}\end{array}$} & \multirow[t]{3}{*}{ no data } & \multirow[t]{3}{*}{ (Present?) $^{b}$} & \multirow[t]{3}{*}{ Absent } & \multirow[t]{3}{*}{ Venezuela } & \multirow[t]{3}{*}{ Absent } \\
\hline & & $\begin{array}{l}10-17-30 \times \\
6-8 \mu \mathrm{m}\end{array}$ & $\begin{array}{l}6.5-7.5 \times \\
4.5-4.8 \mu \mathrm{m}\end{array}$ & & & & & & \\
\hline & & & $\begin{array}{l}(5.5-6 \times 4- \\
4.5 \mu \mathrm{m})^{a}\end{array}$ & & & & & & \\
\hline
\end{tabular}

a Jülich (1978)

b Estimated or indicated in Oberwinkler (1970; Fig. 2) 


\begin{tabular}{|c|c|c|c|c|c|c|c|c|c|}
\hline Taxon & $\begin{array}{l}\text { Hymenophore } \\
\text { type }\end{array}$ & Basidia & Basidiospores & $\begin{array}{l}\text { Cyanobacterial } \\
\text { filaments }\end{array}$ & $\begin{array}{l}\text { Hyphal } \\
\text { sheath }\end{array}$ & $\begin{array}{l}\text { Intracellular } \\
\text { haustoria }\end{array}$ & $\begin{array}{l}\text { Clamp } \\
\text { connections }\end{array}$ & $\begin{array}{l}\text { Type } \\
\text { locality }\end{array}$ & $\begin{array}{l}\text { Sequer } \\
\text { data }\end{array}$ \\
\hline \multirow[t]{3}{*}{ A. phycophila } & \multirow[t]{3}{*}{ resupinate } & clavate; & pyriform, & \multirow[t]{3}{*}{ no data } & \multirow[t]{3}{*}{ no data } & \multirow[t]{3}{*}{ no data } & \multirow[t]{3}{*}{ Absent } & \multirow[t]{3}{*}{ Venezuela } & \multirow[t]{3}{*}{ Absent } \\
\hline & & \multirow[t]{2}{*}{$\begin{array}{l}13-16 \times 5.5- \\
6.5 \mu \mathrm{m}\end{array}$} & $\begin{array}{l}\text { distinctly } \\
\text { broadened) a. }\end{array}$ & & & & & & \\
\hline & & & $\begin{array}{l}5-6-6.5 \times \\
3.5-4 \mu \mathrm{m}\end{array}$ & & & & & & \\
\hline \multirow[t]{2}{*}{ A. poeltii } & \multirow[t]{2}{*}{ resupinate } & $\begin{array}{l}\text { clavate when } \\
\text { mature, more } \\
\text { or less } \\
\text { ellipsoidal } \\
\text { when young; }\end{array}$ & $\begin{array}{l}\text { ovate, } \\
\text { distinctly } \\
\text { broadened } \\
\text { near the base; }\end{array}$ & \multirow[t]{2}{*}{ no data } & \multirow[t]{2}{*}{ no data } & \multirow[t]{2}{*}{ no data } & \multirow[t]{2}{*}{ Present } & \multirow[t]{2}{*}{ USA } & \multirow[t]{2}{*}{ Absent } \\
\hline & & $\begin{array}{l}15-18 \times 5.5- \\
6.5 \mu \mathrm{m}\end{array}$ & $\begin{array}{l}5.5-6 \times 4- \\
4.4 \mu \mathrm{m}\end{array}$ & & & & & & \\
\hline
\end{tabular}

a Jülich (1978)

${ }^{b}$ Estimated or indicated in Oberwinkler (1970; Fig. 2)

Cyphellostereum and four other genera that associate with cyanobacteria (Acantholichen P.M. Jørg., Cora Fr., Corella Vain., and Dictyonema C. Agardh ex Kunth) are now known to form a well-supported monophyletic clade within Hygophoraceae, Agaricales (Dal Forno et al. 2013; Lodge et al. 2014). Recent studies have shown that all of them are lichenized with the filamentous cyanobacterial genus Rhizonema (Lücking et al. 2009; Dal Forno et al. 2021). Until recently, the thallus of Cyphellostereum was characterized by the incomplete enclosure of Rhizonema trichomes by mycelium and the absence of haustoria inside the trichome cells (Dal Forno et al. 2013; Lücking et al. 2013). These traits distinguished Cyphellostereum morphologically from its sister genus, Dictyonema, in which the fungus forms a cellular sheath completely covering the cyanobacterial trichomes, and intracellular haustoria are present. However, some of the very recently described species, placed within Cyphellostereum by molecular sequence analyses, completely enclose their photobiont trichomes with jigsaw-puzzle-like sheaths, or penetrate them with intracellular tubular haustoria as seen in Dictyonema. The definition of Cyphellostereum, therefore, needs to be revised.

Two species of cyanobacteria-associated basidiomycetes, Dictyonema moorei and D. sericeum, have been recorded for Japan (Harada et al. 2004; Ohmura and Kashiwadani 2018). In the course of studying lichenized basidiomycetes in Japan, we found a fungus similar to Cyphellostereum whose mycelium forms a thallus that incompletely surrounds the filamentous cyanobacteria. Molecular phylogenetic analyses of ITS rDNA placed this fungus within a lineage of Cyphellostereum, but it was morphologically different from typical Cyphellostereum species in two ways: it had intracellular haustoria inside the trichome cells, and the basidioma was whitish, resupinate, and membranaceous like Athelia species, neither stipitate nor cyphelloid. Based on these results, we describe the species as Cyphellostereum ushima sp. nov. and revise the definition of the genus Cyphellostereum, taking into account other very recently described members of Cyphellostereum.

\section{Materials And Methods}

\section{Morphological observation}

Macroscopic characters were described based on fresh materials. Microscopic characters were observed in squash preparations of fresh materials mounted in distilled water. For the observation of basidia, the hymenophore was mounted in $3 \% \mathrm{KOH}$ solution after staining with $1 \%$ phloxine B solution. Amyloid reactions were checked using Melzer's reagent ( $1.5 \mathrm{~g}$ potassium iodide, $0.5 \mathrm{~g}$ iodine, $20.0 \mathrm{~g}$ chloral hydrate, $20.0 \mathrm{~mL}$ distilled water). The hymenophore and the lichenized thallus were observed under a stereo-microscope (Olympus SZ 61 and Olympus SZX 16) equipped with a digital camera (Olympus DP21). Microscopic characters of both the mycobiont and the photobiont were observed and measured with differential interference contrast (Olympus BX53, equipped with digital camera DP 73). The length/width ratio (Q) of each spore was given as the range of $Q$ values. To describe the variation of basidiospore size and $Q$ values, $5 \%$ of measurements from each end of the range were placed in parentheses. A voucher specimen has been deposited at the herbarium of the Osaka Museum of Natural History (OSA; Osaka, Japan).

\section{Transmission electron microscopy (TEM)}

For TEM observation, a part of lichenized thallus was embedded in $2 \%(\mathrm{w} / \mathrm{v})$ low gelling temperature agarose type VII-A (Sigma-Aldrich, St. Louis, MO, USA) before fixation. The agar block was pre-fixed in $2.5 \%$ glutaraldehyde in $0.05 \mathrm{M}$ cacodylate buffer $(\mathrm{pH} 7.2)$ for $1 \mathrm{~h}$ at room temperature and rinsed with $0.05 \mathrm{M}$ cacodylate buffer three times for 10 min each time. The block was post-fixed in $1 \%$ osmium tetroxide for $1 \mathrm{~h}$ at room temperature and dehydrated in an ethanol series (10\%, 30\%, 50\%, 70\%, 90\%, for 15 min per step, and 95\% once and 100\% twice for 20 min per step) and embedded in Agar Low Viscosity Resin (Agar Scientific, Stanstead, UK). Ultrathin sections ( $80 \mathrm{~nm}$ thick) were prepared with an RMC MT-X ultramicrotome (RMC products, Arizona, USA). Sections were stained with platinum blue (Inaga et al. 2007) and lead citrate (Venable and Coggeshall 1965). Sections were observed using a transmission electron microscope (HT7700; Hitachi, Tokyo, Japan) at an acceleration voltage of $80 \mathrm{kV}$.

\section{Isolation of the mycobiont}

The collected thallus was moistened with a drop of sterile water and fragmented by sandwiching it between two sterile glass slides that were then rubbed together. The resulting fragments were diluted with sterile water and incubated on modified Detmer's medium (MDM; Watanabe 1960) agar under the 
following condition: $20 \pm 1{ }^{\circ} \mathrm{C}, 20 \mu \mathrm{mol} \mathrm{m} \mathrm{m}^{-2} \mathrm{~s}^{-1}$, and 16h light / 8h dark cycle. The mycobiont isolate (NBRC 115003) was established from the mycelia recovered from the fragments and transferred to potato dextrose agar (PDA; Nissui, Tokyo, Japan), and incubated at $20^{\circ} \mathrm{C}$ for $1-2$ months. We also tried to isolate the mycobiont by attaching a piece of wood containing the hymenium to the lid of a plastic petri dish with mending tape so that basidiospores were discharged onto water agar; the cultures were then incubated at $20^{\circ} \mathrm{C}$ in the dark for one month. The mycobiont culture obtained has been deposited in the NITE Biological Resource Center (NBRC; Kisarazu, Chiba, Japan).

\section{DNA extraction, PCR, and sequencing}

Genomic DNA was extracted from the hymenium, the lichenized thallus, and the mycobiont isolate (NBRC 115003) according to the method of Izumitsu et al. (2012). Polymerase chain reaction (PCR) with KOD FX Neo DNA polymerase (Toyobo, Osaka, Japan) was performed in $20 \mu \mathrm{L}$ reaction volumes containing 1.5 $\mu \mathrm{L}$ of extracted template DNA, $0.4 \mu \mathrm{L}$ of KOD-FX Neo, $10 \mu \mathrm{L}$ of $2 \times$ PCR buffer, $4.0 \mu \mathrm{L}$ of dNTP, $0.3 \mu \mathrm{L}$ each of the two primers $(20 \mu \mathrm{M})$, and $3.5 \mu \mathrm{L}$ of distilled water. The sequence of ITS+28S rDNA (D1/D2) of the mycobiont was amplified with ITS1F (Gardes and Bruns 1993) and LR5 (Vilgalys and Hester 1990) primer pairs, and that of 16S rDNA of the photobiont was amplified with CYA-106F and CYA-781R (Nübel et al. 1997). Multiple attempts to amplify the photobiont $r b c \mathrm{LX}$ using $\mathrm{CX}$ and $\mathrm{CW}$ (Rudi et al. 1998) primer pairs failed, probably because the primers did not correspond to the genome sequence. PCR products were purified by the polyethylene glycol (PEG) precipitation method. Briefly, a 1:1 mixture of PCR product with $0.8 \mathrm{M} \mathrm{NaCl}$ and $6.5 \%$ (w/v) PEG 8000 was centrifuged at $15,000 \mathrm{rpm}$ for $30 \mathrm{~min}$ at $4{ }^{\circ} \mathrm{C}$, washed once with $70 \%$ ethanol, dried at $50{ }^{\circ} \mathrm{C}$ for $1 \mathrm{~h}$, and stored in $20 \mu \mathrm{L}$ TE buffer at $-30{ }^{\circ} \mathrm{C}$. Cycle sequence reactions were conducted using the BigDye Terminator v. 3.1 Cycle Sequencing Kit (Applied Biosystems) using the following primers: ITS1F and ITS4 (White et al. 1990) for the mycobiont ITS (ITS1-5.8S-ITS2), and LROR (Rehner and Samuels 1994), LR5 for the mycobiont 28S rDNA (D1/D2 region), and CYA-106F and CYA-781R for the photobiont 16S rDNA, following the manufacturer's instructions. DNA sequences were analyzed using an ABI PRISM 3130 Genetic Analyzer (Applied Biosystems). All newly generated sequences were deposited in GenBank.

\section{Phylogenetic analyses}

The newly generated mycobiont ITS sequences were aligned with Cyphellostereum sequences from GenBank using the online software MAFFT version 7 with -auto option (Katoh et al. 2019) and manually refined with Seaview v.5.0.4 (Gouy et al. 2010). Eonema pyriforme was selected as outgroup based on Lawrey et al. (2009) and Dal Forno et al. (2019). The phylogenetic analyses for the mycobiont ITS were performed using maximum-likelihood (ML) and Bayesian methods. The optimum substitution models for each data set were estimated using ModelTest-NG v.0.1.6 (Darriba et al. 2020) for the ML analysis and Kakusan4 (Tanabe 2011) for the Bayesian analysis. The ML analysis was performed with RAxML-NG v.0.9.0 (Kozlov et al. 2019). The substitution model TVM+I+G4 was selected as the best-fit model for the ML analysis. Bootstrap proportions (BP) were obtained using 1,000 bootstrap replicates. The Bayesian analysis was performed with MrBayes v.3.2.7a on the CIPRES Science Gateway (Miller et al. 2010; Ronquist et al. 2012) using the substitution model K80+G containing the BIC4 parameter. Two simultaneous and independent Metropolis-coupled Markov Chain Monte Carlo (MCMC) runs were performed for $2,000,000$ generations with the tree sampled for every 1,000 generations of the analyses. The convergence of the MCMC procedure was assessed from the average standard deviation of split frequencies (<0.01) and effective sample size values (>200) using MrBayes and Tracer v.1.7.1 (Rambaut et al. 2018), respectively. The first $25 \%$ of the trees were discarded as burn-in, and the remaining trees were used to calculate the $50 \%$ majority-rule trees and to determine the posterior probabilities (PP) for individual branches.

The newly obtained sequences were submitted to the DNA Data Bank of Japan (DDBJ). The refined alignment of the mycobiont ITS sequences was submitted to TreeBASE (http://www.treebase.org; accession number: 28437). Generated trees were visualized in FigTree v.1.4.4 (https://github.com/rambaut/figtree/) and edited in Inkscape v.1.0.1 (https://inkscape.org).

\section{Results And Discussion}

\section{Morphological observation of Cyphellostereum ushima}

The hymenium of Cyphellostereum ushima is whitish, resupinate, thin, and membranaceous, forming patches adjacent to the lichenized thallus covering the wood surface, especially on margins or underside of the substrate near the thallus (Fig. 1a, b). Basidia are short, about $10 \mu \mathrm{m}$ in length, cylindrical to clavate, and produce four thin-walled hyaline basidiospores (Fig. 1j-I). These morphological features suggest an affinity with Athelia in Atheliales; the phylogenetic analyses, however, did not support such a placement, indicating its inclusion in the Cyphellostereum lineage in Agaricales (see below; Fig. 3). The lichenized thallus is composed of loosely intertwined, lichenized cyanobacterial filaments (Rhizonema trichomes) (Fig. 1c), and does not form a combined structure with hymenium as seen in Dictyonema. The thallus sometimes forms tufts of fibrils of densely arranged fungal-cyanobacterial filaments (Fig. $1 \mathrm{~d}-\mathrm{f}$ ) as seen in $C$. galapagoense (Dal Forno et al. 2017). Each cyanobacterial filament is incompletely surrounded by the mycobiont hyphae (Fig. 1g-i) and different from that of Dictyonema, in which the trichome was completely surrounded by the jigsaw-shaped hyphae sheath. These thallus features are consistent with the conventional definition of Cyphellostereum. However, the mycobiont forms a central haustorium within the trichome, visible with light microscopy (Fig. 1h, i). TEM observation revealed that the surrounding mycobiont hyphae penetrated into the trichome, and longitudinally traversed trichome cells as tubular haustoria (Fig. 2f-i). Such haustoria are commonly seen in Dictyonema, but are unusual in Cyphellostereum, reported only in C. galapagoense so far (Dal Forno et al. 2017). Additionally, Võ (2016) reported the presence of tubular haustoria in three undescribed Cyphellostereum species; further sampling is needed to assess how widespread haustoria are in Cyphellostereum. TEM observation also showed that the haustoria were regularly constricted as they passed through the septa between trichome cells (Fig 2a, b). The presence of the haustorium did not appear to have a significant effect on the division of trichome cells. Thylakoids were irregularly arranged in the photobiont cytoplasm, and electron-dense granules were scattered throughout (Fig. 2d). A barrel-shaped intercalary heterocyte with a thickened wall was observed in the trichome, and its cytoplasm was continuous with the adjacent normal cells through a septal pore (Fig. 2e). The heterocyte contained fewer thylakoids than the neighboring cells and the electron-dense granules were scattered. Intracellular haustoria were frequently observed in vegetative cells, but not in heterocytes. The external mycobiont hyphae occasionally penetrated trichome cells and were 
constricted considerably in the cell wall of the trichome (haustorial neck) (Fig. $2 \mathrm{f}-\mathrm{i}$ ). The width of the haustoria neck was less than $1 \mu \mathrm{m}$, and although the cytoplasm of the external hyphae and intracellular haustoria was continuous, the wall of the hypha seemed to be discontinuous in the thin sections observed (Fig. 2g, i). Compared with the cell wall thickness of the external hyphae (about $150 \mathrm{~nm}$ ), that of the intracellular haustoria was much thinner (about $50 \mathrm{~nm}$ ).

TEM observations of Cyphellostereum are reported here for the first time. However, two structurally similar genera, Cora and Dictyonema, were previously observed with TEM (Roskin 1970; Oberwinkler 1980, 1984; Slocum 1980). The observation of the thallus of $C$. ushima was essentially consistent with these observations. On the other hand, the following characters could not be detected in this study: the dark staining material at the site of penetration observed in $D$. irpicinum (Slocum 1980), the multilayered scar of the haustorial mother cells, and the electron-dense ring around the haustorial neck observed in $D$. sericeum (Oberwinkler 1980). The wall of the tubular intracellular haustoria was thinner than that of the external hyphae, as observed in D. irpicinum (Slocum 1980), and consistent with the idea that the haustorium facilitates the transport of metabolites from photobiont to mycobiont. Unlike Dictyonema, which always forms tubular intracellular haustoria, there are many species of Cyphellostereum for which tubular intracellular haustoria have been reported as absent in light microscope observations. These need to be investigated in more detail with TEM in the future. In Ascomycota, several genera are known to lichenize Rhizonema, including Coccocarpia (Lücking et al. 2009) and Erioderma (Cornejo et al. 2016) in Lecanoromycetes, and Lichinodium (Prieto et al. 2019) in Leotiomycetes. However, TEM observations of Coccocarpia (Arvidsson 1982) and Lichinodium (Prieto et al. 2019) showed that while mycobiont hyphae are in close contact with algal cells, the intracellular haustoria were not formed. Thus, at present, only basidiomycetes are known to form tubular intracellular haustoria within Rhizonema trichome cells.

\section{Comparison between $C$. ushima and other known Cyphellostereum species}

Cyphellostereum ushima is unusual in Cyphellostereum in that the fruiting body is resupinate and membranaceous, forming tubular haustoria, and is easily distinguished from other known Cyphellostereum species (Table 1). However, in recent years, some species other than $C$. ushima have been described with characteristics deviating from the conventional recognition of Cyphellostereum, although they are phylogenetically placed in the Cyphellostereum lineage, a phylogenetically well-supported monophyletic clade. For example, C. galopagoense was originally described as Dictyonema because the trichome was completely surrounded by the jigsaw-shaped hyphal sheath cells (Yánez et al. 2012), but subsequent molecular analysis resulted in its assignment to the Cyphellostereum clade (Dal Forno et al. 2017). Cyphellostereum galapagoense is also unusual in that tubular haustoria are formed in the trichome cells (Dal Forno et al. 2017), as occurs in C. ushima. In addition, C. georgianum and C. jamesianum are unique in that clamp connections are observed in the vegetative hyphae (Dal Forno et al. 2019).

\section{Isolation of Cyphellostereum ushima}

Basidiospores discharged onto agar did not germinate at all after one month of incubation in the dark at $20^{\circ} \mathrm{C}$. Some additional factors such as the presence of the photobiont may be needed for germination. On the other hand, regrowth of vegetative hyphae from the thallus fragments was observed on rare occasions (Fig. 1m), and an axenic mycobiont isolate was established by transferring the elongated mycelium to a new PDA medium (Fig. 1n). The identity of the mycobiont culture and its relationship to other taxa of Cyphellostereum were analyzed as detailed below.

\section{Molecular analyses}

The ML and Bayesian phylogenetic analyses were conducted using an aligned sequence dataset composed of 405 bp from the mycobiont ITS. The tree topology inferred by the Bayesian analysis was mostly identical to that of the ML tree, except for unsupported branches in the ML tree. The sequences of $C$. ushima formed a strongly supported monophyletic clade (100\% ML BP/1.00 Bayesian PP) with the sequences of $C$. unoquinoum (KY861495) and $C$. phyllogenum (KF443219), and they were located in a unique lineage within the clade (Fig. 3). These three species all lack clamp connections in vegetative hyphae, and incompletely cover the cyanobacterial symbiont filaments. However, C. phyllogenum and C. unoquinoum differ from C. ushima in that they lack tubular internal haustoria. Cyphellostereum galapagoense, the only other species of Cyphellostereum known to have tubular internal haustoria (Dal Forno et al. 2017), is in a distant lineage from C. ushima; our phylogenetic analysis does not support genetic relatedness between the two.

The BLAST search of the sequence of 16S rDNA (GenBank accession no. LC597370) derived from the lichenized thallus of $C$. ushima indicated that the photobiont is Rhizonema species. Similarly, we tried to get the $r b c \mathrm{LX}$ sequence from the thallus, but $r b c \mathrm{LX}$ could not be amplified despite multiple attempts. The primers for CX and/or CW are probably not compatible with the photobiont genome. Referring to figure S9 of Dal Forno et al. (2021) on the delimitation of Rhizonema species based on the sequences of $16 \mathrm{~S}$ rDNA and $r b c \mathrm{LX}$, the 16S rDNA sequences obtained agreed with those specific to $R$. interruptum in 6 out of 7 diagnostic positions. Therefore, the photobiont of $C$. ushima is closely related to $R$. interruptum, but the $r b c \mathrm{LX}$ sequence will be needed for more precise identification.

\section{Similarities between $C$. ushima and some lichenized Athelia species}

In addition to the lichenized monophyletic group including such as Cyphellostereum and Dictyonema in Hygrophoraceae, three Athelia species ( $A$. andina, $A$. phycophila, and A. poeltii) are also known to be lichenized with filamentous cyanobacteria (Jülich 1972, 1978) (Table 1). However, none of these lichenized Athelia species has been reliably reported since their original description, and all lack DNA information. The descriptions of these species do not include detailed information on the lichenized thallus, except for the sketch and observations of $A$. andina by Oberwinkler (1970, 2012), and thus they remain poorly known taxa even as lichens. Since all basidiomata of lichenized Athelia species are whitish, resupinate, and membranaceous, they have never been compared with Cyphellostereum species, whose basidiomata have been recognized as cyphelloid. The basidioma of $C$. ushima has many similarities with the abovementioned lichenized Athelia species, especially with those of $A$. phycophila, but $C$. ushima is morphologically distinguished by its shorter basidia and ellipsoid to slightly elongate basidiospores (vs pyriform in A. phycophila). The basidioma of Eonema pyriforme, a non-lichenized sister lineage of Cyphellostereum, is whitish and resupinate like that of Athelia, and, in fact, used to be treated as Athelia pyriformis (Jülich 1972) until phylogenetic analysis 
placed it in Hygrophoraceae (Lawrey et al. 2009). The fact that the basidioma of $C$. ushima is similar to those of lichenized Athelia species suggests that the latter may actually be part of the Cyphellostereum lineage. Their phylogenetic affiliations will have to be verified by examining type specimens, re-collecting in the type localities, and further molecular work.

Oberwinkler (1970) reported that both $C$. pusiolum and $A$. andina are associated not only with filamentous cyanobacteria but also with unicellular green algae to form a Botrydina-type thallus. Although he did not elaborate on the Botryodina-type thallus, his subsequent reviews of basidiolichens retain the view that the mycelia of both species form distinct thalli with filamentous cyanobacteria and unicellular green algae simultaneously (Oberwinkler 2012). On the other hand, Jülich (1972), in his official description of $A$. andina, refers to lichenization with cyanobacteria (as Scytonema), but does not mention green algae. Our observations of the thallus of $C$. ushima showed that the mycelium lichenized only Rhizonema trichomes; no interaction with other algae was observed. While dual relationships with both green algae and cyanobacteria are well-documented in certain ascolichens (particularly in Peltigerales), similar reports in basidiolichens need further study.

\section{Taxonomy}

Here we describe Cyphellostereum ushima with data on both the matured basidioma and the lichenized thallus. The circumscription of Cyphellostereum is emended as follows to encompass the features of other recently described species mentioned above.

Cyphellostereum D.A. Reid, Beih. Nova Hedwigia 18: 336 (1965), emend. H. Masumoto \& Y. Degawa

Emended diagnosis: Basidiomata terrestrial, saxicolous, muscicolous, or lignicolous, whitish, sessile (resupinate) or stipitate (fan-shaped), separated from the thallus or only at the base connected to the thallus. Hyphae thin-walled, with or without clamp connections, monomitic. Cystidia absent. Basidia clavate to cylindrical, with 4 sterigmata and a simple basal septum. Basidiospores subglobose to ellipsoid, smooth, thin-walled, non-amyloid. Thallus blue-green to greenish, crustose, composed of cyanobacterial filaments, without haustoria or with tubular intracellular haustoria. Photobiont Rhizonema, cells cylindrical, uniseriate, with cylindrical to rounded intercalary heterocytes, occasionally forming false branches. Hyphal sheath around cyanobacterial filaments composed of irregular hyphae leaving interspaces, or composed of jigsaw-puzzle-shaped paraplectenchymatous fungal cells completely ensheathing the photobiont trichome.

Cyphellostereum ushima H. Masumoto \& Y. Degawa, sp. nov. (Figs. 1 and 2)

MycoBank no.: MB XXXXX.

Holotype: JAPAN. Kagoshima, Amami-Oshima, Setouchi, Amurogama, on tree trunks of Cryptomeria japonica, elevation 15 m, 6 Mar 2020 , H. Masumoto 364 (OSA-MY-9529, ex-type culture: NBRC 115003).

Etymology. From the island name of the type locality (Amami-Oshima) in Amami language (Ushima).

Description: Thallus epiphytic on tree trunks (Cryptomeria japonica), undifferentiated, membranous, developing a mat of loosely interwoven fungalcyanobacterial fibrils, fragile, green to bluish-green. Thallus in section up to $80 \mu \mathrm{m}$ thick; occasionally with tufts of fibrils up to $300 \mu \mathrm{m}$ long from base, formed by densely arranged fungal-cyanobacterial filaments. Thallus composed of cyanobacterial filaments (Rhizonema trichomes) incompletely surrounded by hyaline hyphae (fungal sheath), 2.7-3.5 $\mu \mathrm{m}$ diam; trichome cells 5.5-8.6 $\mu \mathrm{m}$ wide $\times 3.3-7.3 \mu \mathrm{m}$ high, green to bluish-green, uniseriate, occasionally false branched; trichome cells penetrated by tubular fungal hyphae (haustoria) of 2.5-3.4 $\mu \mathrm{m}$ diam; heterocytes sparse, pale yellow, 5.5-10.0 $\mu \mathrm{m}$ wide and $4.0-10$ $\mu \mathrm{m}$ high, cylindrical to broadly ellipsoid; clamp connections not observed. Basidiomata formed on margins or underside of the substrate near the thallus, resupinate, effuse, very thin, arachnoid, whitish, free of cyanobacterial filament; hymenophore in section up to $40 \mu \mathrm{m}$ thick. Hyphal system monomitic, consisting of branched, hyaline generative hyphae, smooth, thin-walled, 3-4(-5) $\mu \mathrm{m}$ wide lacking clamp connections. Cystidia absent. Basidia (8.6-)9.4$13.0(-15.4) \times(4.9-) 5.4-6.5(-7.1) \mu \mathrm{m}, 11.19 \pm 1.83 \times 5.94 \pm 0.58 \mu \mathrm{m}$ on average with standard deviation (std) $(\mathrm{n}=24), 4$-spored, clavate or short-cylindrical, thin-walled, hyaline, with a simple basal septum; sterigmata 2.2-3.6 $\mu \mathrm{m}$. Basidiospores (4.6-)5.3-6.3(-6.9) $\times(3.0-) 3.4-4.0(-4.3) \mu \mathrm{m}, 5.76 \pm 0.50 \times 3.69 \pm$ $0.31 \mu \mathrm{m}$ on average with std $(n=50), Q=(1.3-) 1.4-1.6(-1.8), 1.57 \pm 0.14$ on average with std $(n=50)$, ellipsoid to slightly elongate, hyaline, smooth, thinwalled, non-amyloid. Colonies on PDA slow-growing, reaching $4.0-4.5 \mathrm{~mm}$ in diam after 2 months at $20^{\circ} \mathrm{C}$ in the dark, three-dimensional, aggregated, palepink to pale-brown, the mycelium hardly extending into the agar.

Distribution: Currently found only in the type locality (Amami-Oshima, Kagoshima, Japan). This is the first report of the genus Cyphellostereum in Japan.

Gene sequences of the holotype: LC597364 (ITS1-5.8S-ITS2), LC597367 (28S rDNA)

Gene sequences of the ex-type culture: LC597366 (ITS1-5.8S-ITS2), LC597369 (28S rDNA)

Japanese name: Taorugoke (Taoru, meaning a towel, refers to the loosely interwoven texture of the thallus; -goke, a suffix often used to mean a lichen).

\section{Declarations}

\section{Ethics declarations}

\section{Ethics approval and Consent to participate}

Not applicable. 


\section{Consent for publication}

Not applicable.

\section{Conflict of interest}

The authors declare no competing interests.

\section{Availability of data and materials}

The holotype specimen of Cyphellostereum ushima described in this study was deposited in the herbarium of the Osaka Museum of Natural History (OSA; Osaka, Japan). The ex-type living culture was deposited in the NITE Biological Resource Center (NBRC; Kisarazu, Chiba, Japan). All sequence data generated in this study are available at GenBank (https://www.ncbi.nlm.nih.gov/genbank/). The alignment file can be accessed via TreeBASE (http://www.treebase.org).

\section{Funding}

This study was funded by the Japan Society for the Promotion of Science (JSPS) Grants-in-Aid for Scientific Research (KAKENHI) $19 \mathrm{~J} 11217$ (to HM) and $19 \mathrm{H} 03281$ (to YD).

\section{Authors' contributions}

All authors contributed to the study conception and design. Isolation and identification of Cyphellostereum ushima were completed by HM. Morphological characteristics were measured and documented by HM. Molecular and phylogenetic analyses were completed by HM. Culture deposition and sequence submission were completed by HM. The first draft of the manuscript was written by HM and all authors commented on previous versions of the manuscript. This study was supervised by YD. All authors read and approved the final manuscript.

\section{Acknowledgment}

We address special thanks to Dr. William B. Sanders for his valuable comments throughout the manuscript.

\section{References}

1. Arvidsson L (1982) A monograph of the lichen genus Coccocarpia. Opera Bot 67: 1- 86

2. Cornejo C, Nelson PR, Stepanchikova I, Himelbrant D, Jorgensen PM, Scheidegger C (2016) Contrasting pattern of photobiont diversity in the Atlantic and Pacific populations of Erioderma pedicellatum (Pannariaceae). Lichenologist 48: 275-291. https://doi.org/10.1017/S0024282916000311

3. Dal Forno M, Lawrey JD, Sikaroodi M, Bhattarai S, Gillevet PM, Sulzbacher M, Lücking R (2013) Starting from scratch: Evolution of the lichen thallus in the basidiolichen Dictyonema (Agaricales: Hygrophoraceae). Fungal Biol 117: 584-598. https://doi.org/10.1016/j.funbio.2013.05.006

4. Dal Forno M, Bungartz F, Yánez-Ayabaca A, Lücking R, Lawrey JD (2017) High levels of endemism among Galapagos basidiolichens. Fungal Divers 85: 45-73. https://doi.org/10.1007/s13225-017-0380-6

5. Dal Forno M, Kaminsky L, Rosentreter R, Mcmullin RT, Aptroot A, Lücking R (2019) A first phylogenetic assessment of Dictyonema s.lat. in southeastern North America reveals three new basidiolichens, described in honor of James D. Lawrey. Plant Fungal Syst 64: 383-392. https://doi.org/10.2478/pfs2019-0025

6. Dal Forno M, Lawrey JD, Sikaroodi M, Gillevet PM, Schuettpelz E, Lücking R (2021) Extensive photobiont sharing in a rapidly radiating cyanolichen clade. Mol Ecol 30: 1755-1776. https://doi.org/10.1111/mec.15700

7. Darriba D, Posada D, Kozlov AM, Stamatakis A, Morel B, Flouri, T $₫ 2020 \bigotimes$ ModelTest-NG: a new and scalable tool for the selection of DNA and protein evolutionary models. Mol Biol Evol 37: 291-294. https://doi.org/10.1093/molbev/msz189

8. Ertz D, Guzow-Krzemińska B, Thor G, Łubek A, Kukwa M (2018) Photobiont switching causes changes in the reproduction strategy and phenotypic dimorphism in the Arthoniomycetes. Sci Rep 8: 4952. https://doi.org/10.1038/s41598-018-23219-3

9. Gardes M, Bruns TD (1993) ITS primers with enhanced specificity for basidiomycetes - application to the identification of mycorrhizae and rusts. Mol Ecol 2: 113-118. https://doi.org/10.1111/j.1365-294X.1993.tb00005.x

10. Gouy M, Guindon S, Gascuel O (2010) SeaView version 4: a multiplatform graphical user interface for sequence alignment and phylogenetic tree building Mol Biol Evol 27: 221-224

11. Harada H, Okamoto T, Yoshimura I (2004) A checklist of lichens and lichen-allies of Japan. Lichenology 2: 47-165

12. Inaga S, Katsumoto T, Tanaka K, Kameie T, Nakane H, Naguro T (2007) Platinum blue as an alternative to uranyl acetate for staining in transmission electron microscopy. Arch of Histol Cytol 70: 43-49

13. Izumitsu K, Hatoh K, Sumita T, Kitade Y, Morita A, Gafur A, Ohta A, Kawai M, Yamanaka T, Neda H, Ota Y, Tanaka C (2012) Rapid and simple preparation of mushroom DNA directly from colonies and fruiting bodies for PCR. Mycoscience 53: 396-401. https://doi.org/10.1007/s10267-012-0182-3

14. Jülich W (1972) Monographie der Athelieae (Corticiaceae, Basidiomycetes). Willdenowia Beih 7: 1-283

15. Jülich W (1978) A new lichenized Athelia from Florida. Persoonia 10: 149-151

16. Katoh K, Rozewicki J, Yamada KD (2019) MAFFT online service: multiple sequence alignment, interactive sequence choice and visualization. Brief Bioinform 20: 1160-1166. https://doi.org/10.1093/bib/bbx108 
17. Kozlov AM, Darriba D, Flouri T, Morel B, Stamatakis A (2019) RAxML-NG: A fast, scalable and user-friendly tool for maximum likelihood phylogenetic inference. Bioinformatics 35: 4453-4455. https://doi.org/10.1093/bioinformatics/btz305

18. Lawrey JD, Lücking R, Sipman HJM, Chaves JL, Redhead SA, Bungartz F, Sikaroodi M, Gillevet PM (2009) High concentration of basidiolichens in a single family of agaricoid mushrooms (Basidiomycota: Agaricales: Hygrophoraceae). Mycol Res 113: 1154-

1171. https://doi.org/10.1016/j.mycres.2009.07.016

19. Lodge DJ, Padamsee M, Matheny PB, Aime MC, Cantrell SA, Boertmann DM, Kovalenko A, Moncalvo JM, Vilgalys R, Vizzini A, Larsson E, Lücking R, Griffith GW, Smith M, Norvell L, Desjardin DE, Redhead S, Ovrebo CL, Lickey EB, Ercole E, Hughes KW, Courtecuisse R, Young A, Binder M, Minnis A, Lindner DL, Ortiz-Santana B, Haight J, Læssøe T, Baroni TJ, Geml J, Hattori T (2014) Molecular phylogeny, morphology, pigment chemistry and ecology in Hygrophoraceae (Agaricales). Fungal Divers 64: 1-99. https://doi.org/10.1007/s13225-013-0259-0

20. Lücking R, Lawrey JD, Sikaroodi M, Gillevet PM, Chaves JL, Sipman HJM, Bungartz F (2009) Do lichens domesticate photobionts like farmers domesticate crops? Evidence from a previously unrecognized lineage of filamentous cyanobacteria. Am J Bot 96: 1409-1418. https://doi.org/10.3732/ajb.0800258

21. Lücking R, Dal Forno M, Lawrey JD, Bungartz F, Holgado Rojas ME, Hernández MJE, Marcelli MP, Moncada B, Morales EA, Nelsen MP, Paz E, Salcedo L, Spielmann A. A, Wilk K, Will-Wolf S, Yánez A (2013) Ten new species of lichenized Basidiomycota in the genera Dictyonema and Cora (Agaricales: Hygrophoraceae), with a key to all accepted genera and species in the Dictyonema clade. Phytotaxa 139: 138. https://doi.org/10.11646/phytotaxa.139.1.1

22. Lücking R, Timdal E (2016) New species of Dictyonema and Cyphellostereum (lichenized Basidiomycota: Hygrophoraceae) from tropical Africa and the Indian Ocean, dedicated to the late Hildur Krog. Willdenowia 46: 191-199

23. Miller MA, Pfeiffer W, Schwartz T (2010) Creating the CIPRES Science Gateway for inference of large phylogenetic trees. In: Proceedings of the Gateway Computing Environments Workshop (GCE). New Orleans, Louisiana. pp. 1-8. https://doi.org/10.1109/GCE.2010.5676129

24. Nübel U, Garcia-Pichel F, Muyzer G (1997) PCR primers to amplify 16S rRNA genes from cyanobacteria. Appl Environ Microbiol 63: $3327-3332$

25. Oberwinkler F (1970) Die Gattungen der Basidiolichenen. Neue Folge Ber Dtsch Bot Ges 4: 139-169

26. Oberwinkler F (1980) Symbiotic relationships between fungus and alga in basidiolichens. In: Schwemmler W, Schenk HEA (eds) Endocytobiology Endosymbiosis and Cell Biology A Synthesis of Recent Research. Walter de Gruyter \& Co., Berlin, pp. 305-315

27. Oberwinkler $F$ (1984) Fungus-alga interactions in basidiolichens. Nova Hedwig Beih 79: 739-774

28. Oberwinkler F (2012) Basidiolichens. In: Hock B (ed) The Mycota: fungal associations IX, 2nd edn. Springer-Verlag, Berlin, pp 341-362

29. Ohmura Y, Kashiwadani H (2018) Checklist of lichens and allied fungi of Japan. Natl Mus Nat Sci Monogr 49: 1-143

30. Parmasto E (1978) The genus Dictyonema (Thelephorolichenes). Nova Hedwigia 24: 99-138

31. Prieto M, Schultz M, Olariaga I, Wedin M (2019) Lichinodium is a new lichenized lineage in the Leotiomycetes. Fungal Divers $94: 23-39$. https://doi.org/10.1007/s13225-018-0417-5

32. Rambaut A, Drummond AJ, Xie D, Baele G, Suchard MA (2018) Posterior summarisation in Bayesian phylogenetics using Tracer 1.7. Syst Biol 67: 901904

33. Rehner SA, Samuels GJ (1994) Taxonomy and phylogeny of Gliocladium analysed from nuclear large subunit ribosomal DNA sequences. Mycol Res 98(6): 625-634. https://doi.org/10.1016/S0953-7562(09)80409-7

34. Reid DA (1965) A monograph of the stipitate stereoid fungi. Nova Hedwig Beih 18: 1-384

35. Ronquist F, Teslenko M, van der Mark P, Ayres DL, Darling A, Höhna S, Larget B, Liu L, Suchard MA, Huelsenbeck JP (2012) MrBayes 3.2: Efficient bayesian phylogenetic inference and model choice across a large model space. Syst Biol 61: 539-542

36. Roskin PA (1970) Ultrastructure of the host-parasite interaction in the basidiolichen Cora pavonia (Web.) E. Fries. Arch Mikrobiol 70: 176-182. https://doi.org/10.1007/BF00412209

37. Rudi K, Skulberg OM, Jakobsen KS (1998) Evolution of cyanobacteria by exchange of genetic material among phyletically related strains. J Bacteriol 180: 3453-3461

38. Ryvarden L (2010) Stereoid fungi of America. Synopsis Fungorum 28: 1-206

39. Slocum D (1980) Light and electron microscopic investigations in the Dictyonemataceae (basidiolichens). II. Dictyonema irpicinum. Can J Bot 58:10051015

40. Tanabe AS (2011) Kakusan4 and Aminosan: two programs for comparing nonpartitioned, proportional and separate models for combined molecular phylogenetic analyses of multilocus sequence data. Mol Ecol Resour 11: 914-921

41. Venable JH, Coggeshall R (1965) A simplified lead citrate stain for use in electron microscopy. J Cell Biol 25: 407-408

42. Vilgalys R, Hester M (1990) Rapid genetic identification and mapping of enzymatically amplified ribosomal DNA from several Cryptococcus species. J Bacteriol 172(8): 4238-4246. https://doi.org/10.1128/jb.172.8.4238-4246.1990

43. Võ GTP (2016) Cyanobacterial lichenized fungi and their photobionts in Vietnam. Ph.D. Dissertation, Technische Universität Kaiserslautern, Germany

44. Watanabe A (1960) List of algal strains in collection at the institute of applied microbiology, University of Tokyo. J Gen Appl Microbiol 6: 283-292. https://doi.org/10.2323/jgam.6.283

45. White TJ, Bruns T, Lee S, Taylor JW (1990) Amplification and direct sequencing of fungal ribosomal RNA genes for phylogenetics. In: Innis MA, Gelfand DH, Sninsky JJ, White TJ (eds) PCR Protocols: A Guide to Methods and Applications. Academic Press, New York, pp. 315-322 
46. Yánez A, Dal Forno M, Bungartz F, Lücking R, Lawrey JD (2012) A first assessment of Galapagos basidiolichens. Fungal Divers 52: 225244. https://doi.org/10.1007/s13225-011-0133-x

\section{Figures}
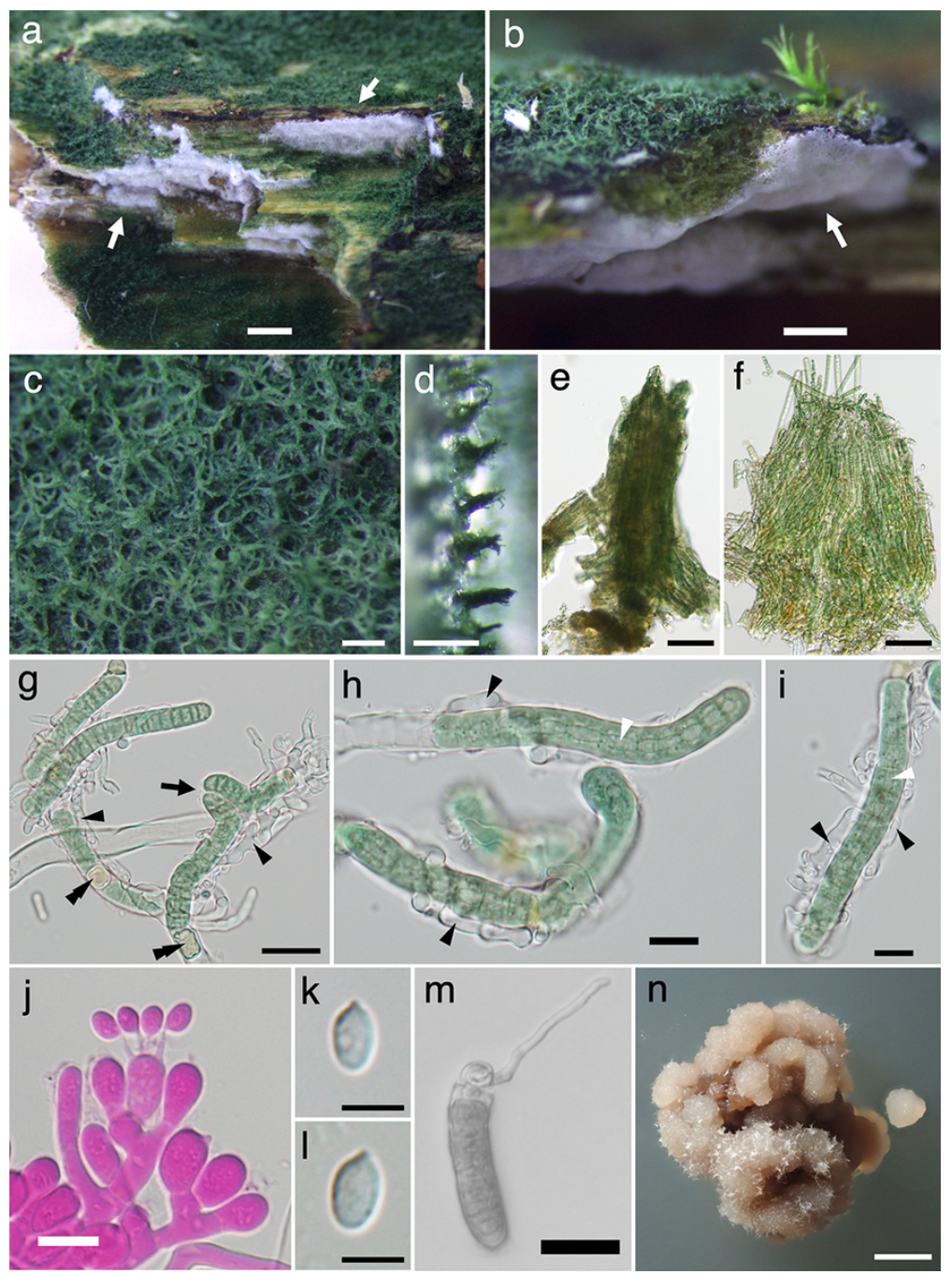

\section{Figure 1}

Cyphellostereum ushima (OSA-MY-9529, holotype). a, b Resupinate basidiomata (white arrows) and fibrous lichenized thallus. Note that the basidiomata are formed on the edge or underside of the wood. c Higher magnification of the lichenized thallus. Note that the intricate interweaving of cyanobacterial filaments. d Fibrils condensed. e Arrangement of the fibrils. f Squashed fibrils of e. g Mycobiont hyphae (black arrowheads) incompletely surrounding the Rhizonema trichome. Note that the sparse heterocytes in the trichome (double arrowheads) and the double false branch of the trichome (black arrow). $\mathrm{h}$, i Higher magnification of the trichome. Note the tubular intracellular haustoria (white arrowheads) inside the trichome. $\mathrm{j}$ Basidium mounted in $3 \% \mathrm{KOH}$ and stained with $1 \%$ phloxine B solution. $\mathrm{k}$, I Basidiospores. $\mathrm{m}$ Mycelium extending from the thallus fragment. $\mathrm{n}$ Aposymbiotic culture of mycobiont (NBRC 115003 , extype) grown on PDA for two months at $20^{\circ} \mathrm{C}$. Scale bars: $\mathrm{a}, \mathrm{n}=1 \mathrm{~mm} ; \mathrm{b}=500 \mu \mathrm{m} ; \mathrm{d}=300 \mu \mathrm{m} ; \mathrm{c}=100 \mu \mathrm{m} ; \mathrm{e}, \mathrm{f}=50 \mathrm{~mm} ; \mathrm{g}, \mathrm{m}=20 \mu \mathrm{m} ; \mathrm{h}-\mathrm{j}=10 \mu \mathrm{m} ; \mathrm{k}, \mathrm{I}=5$ $\mu \mathrm{m}$. 


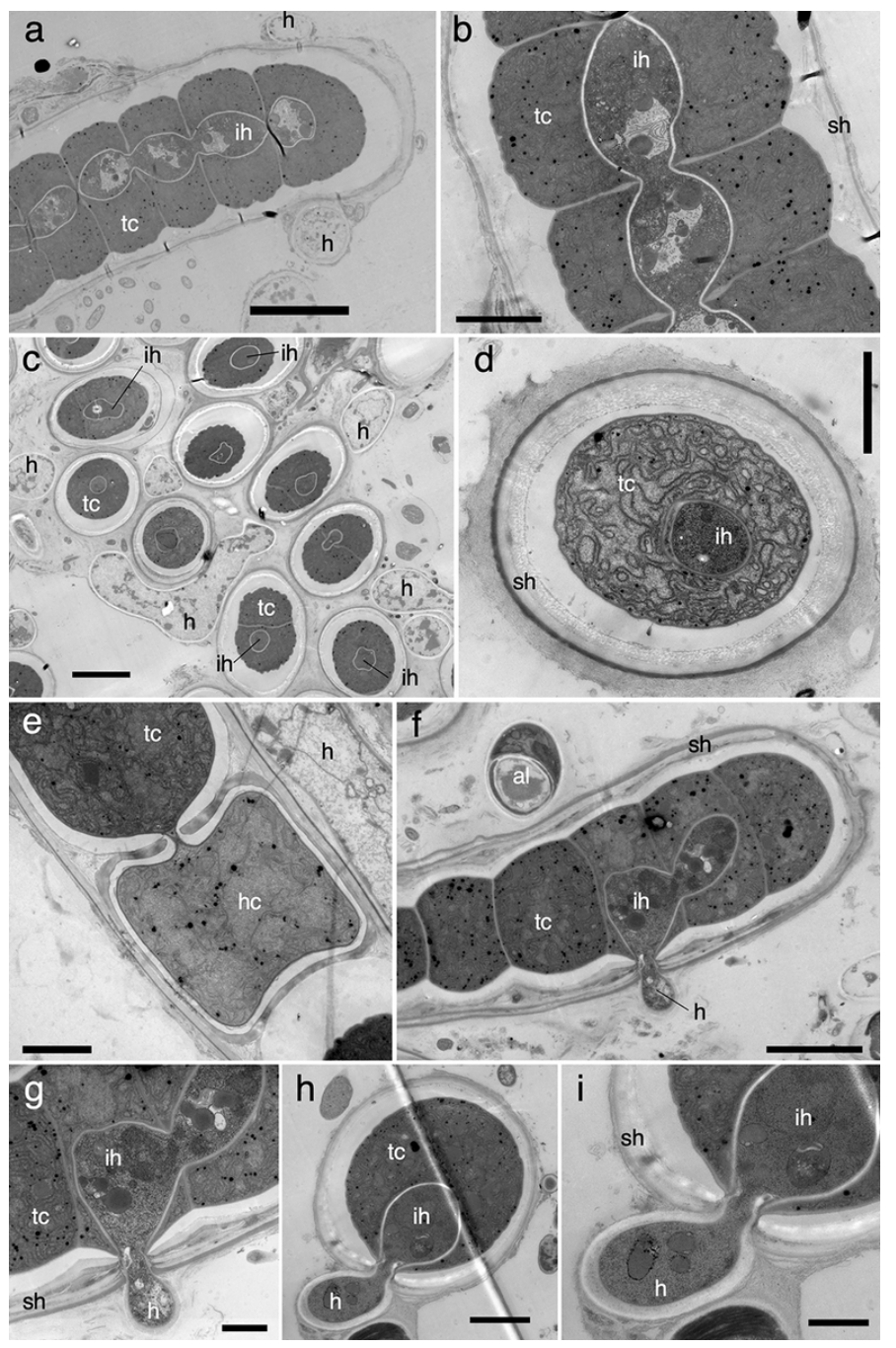

\section{Figure 2}

TEM photographs of the lichenized thallus of Cyphellostereum ushima (OSA-MY-9529, holotype). a Longitudinal section of Rhizonema trichome. Note that the tubular intracellular haustoria are regularly constricted at the septa of the trichome cells. b Higher magnification of the longitudinal section in a. c Transverse section of Rhizonema trichome. Note the presence of intracellular haustoria in all trichome cells. d Higher magnification of the transverse section in c. e Heterocyte. Note that a distinct greyish layer all around the heterocyte and the cytoplasm of the heterocyte is continuous with the neighboring normal cell via a septal pore. f Longitudinal section of intracellular haustoria with external hyphae invading the trichome. $\mathrm{g}$ Higher magnification of the longitudinal section in $\mathrm{f}$. Note continuity of cytoplasm of external hyphae and intracellular haustoria. $\mathrm{h}$ Transverse section of intracellular haustoria and external hyphae invading the trichome. i Higher magnification of the transverse section in g. Note that the wall of the external hyphae and the wall of the intracellular haustoria do not appear to be continuous in this section. al = an epiphytic algal cell on the thallus, $\mathrm{h}=$ mycobiont hyphae, ih = intracellular haustoria, sh $=$ sheath of the photobiont, tc $=$ trichome cells. Scale bars: $a, c=5 \mu \mathrm{m} ; \mathrm{f}=3 \mu \mathrm{m} ; \mathrm{b}, \mathrm{d}, \mathrm{e}, \mathrm{h}=2 \mu \mathrm{m} ; \mathrm{g}, \mathrm{i}=1 \mu \mathrm{m}$ 


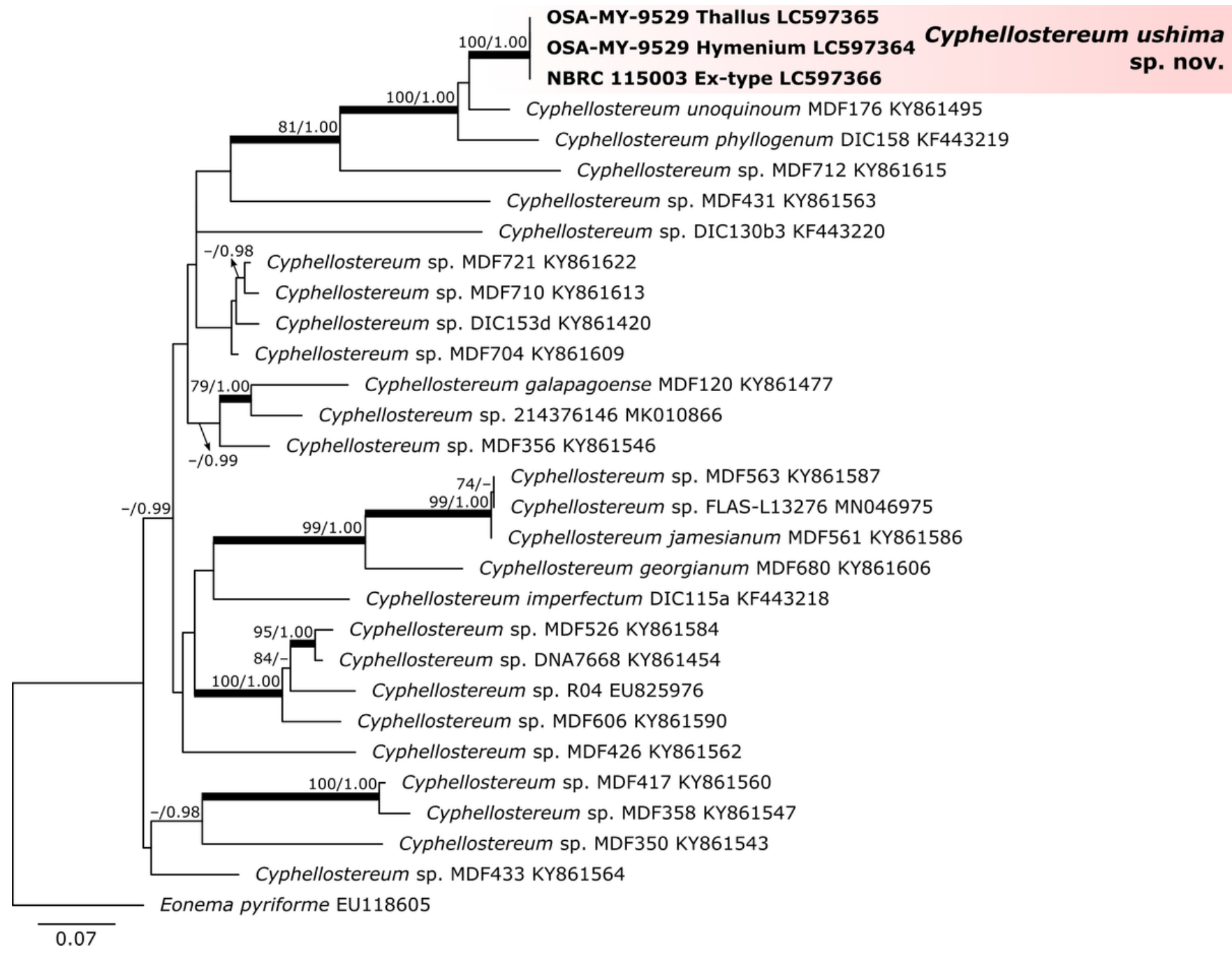

Figure 3

Maximum-likelihood (ML) tree of Cyphellostereum based on ITS rDNA sequences, showing the placement of C. ushima. ML-bootstrap proportion (BP) $\geq 70 \%$ and Bayesian posterior probabilities (PP) $\geq 0.95$ are indicated. Branches supported by ML-BP $\geq 70 \%$ and PP $\geq 0.95$ are shown in thick lines. Sequences obtained in this study are shown in bold. The scale bar represents the nucleotide substitutions per site. 